\title{
Level of the nuclear factor c-Fos in human aldosteroma cells after potassium treatment
}

O.S. Lukashenia, N.I. Levchuk

State Institution «V.P. Komisarenko Institute of Endocrinology and Metabolism of the National

Academy of Medical Sciences of Ukraine», Kyiv, Ukraine

\begin{abstract}
Potassium ions play an important role in the regulation of steroidogenesis, water-salt balance, apoptosis, proliferation. However, the nuclear phase of the agonist signaling in adrenocorticocytes remains poorly understood. The aim of the work was to elucidate the effect of potassium on the level of nuclear transcription factor c-Fos in human tumor adrenocortical tissue (aldosteroma). Methods. Expression of c-Fos transcription factor in aldosteromas was detected using Western-blot analysis. Results. The increase of c-Fos level in human aldosteroma cells at potassium physiological concentration of $3.5 \mathrm{mmol} / \mathrm{l}$ compared to medium without potassium was observed. The level of cFos did not change after $8.5 \mathrm{mmol} / \mathrm{l} \mathrm{K}^{+}$administration. The possible participation of transcription factor c-Fos in steroidogenic effects of $\mathrm{K}^{+}$is being discussed. Conclusions. The results of study suggest that $\mathrm{K}^{+}$can have a direct effect on the expression level of nuclear transcription factor c-Fos in tissues from human aldosteromas.
\end{abstract}

Keywords: $\mathrm{K}^{+}$, human adrenocorticocytes, aldosteroma, transcription factors.

Potassium is one of the major regulators of mineral corticoid function in the adrenal cortex. The response to potassium is associated with a rapid increase in aldosterone secretion. On the other hand, $\mathrm{K}^{+}$is known as principal regulator of apoptosis in the adrenal and other tissues [1- 3]. Although $\mathrm{K}^{+}$ stimulates an increase in cAMP formation and cAMP-dependent protein kinase A [4], other secondary messengers including protein kinase $\mathrm{C}$ (PKC) [5, 6], $\mathrm{Ca}^{2+}$-calmodulin-dependent protein kinase [7] are also activated by potassium. Stimuli

* Адреса для листування (Correspondence): ДУ «Інститут ендокринології та обміну речовин ім. В.П. Комісаренка НАМН України», вул. Вишгородська, 69, м. Київ, 04114 , Україна. Email: LukashenyaOksana@gmail.com

๑ О.С. Лукашеня, Н.I. Левчук that involve $\mathrm{PKC}$ and $\mathrm{Ca}^{2+}$-calmodulin dependent protein kinase also induce members of the mitogenactivated protein kinase (MAPK) family of serine/ threonine kinases [2]. MAPK include c-Jun Nterminal kinase (JNK), p42/p44 ERK1/2 (extracellular signal-regulated kinase) and p38 kinase. These serine/threonine kinases activate downstream transcription factors, which in turn induce expression of target genes. The transcription factors c-Jun, c-Fos, NF-kB were stimulated by $\mathrm{K}^{+}$in different types of cells $[8,9,10]$. Effects of $\mathrm{K}^{+}$differ in normal and tumor adrenocortical tissues. It was shown that the adrenal tumor tissue is less sensitive to proapoptotic action of potassium [1]. 
The aim of this work was to elucidate the effect of potassium in the human tumor adrenocortical tissue on the level of MAPK-dependent transcription factor cFos.

\section{Materials and methods}

Material. All the salts were provided by Merck (Germany); Tween 20 - by Ferak (Germany); HEPES, BSA ( $\mathrm{V}$ fraction, content of lipids less than $0.1 \%$ ) - by Serva (Germany). Lysis buffer, primary and secondary antibodies for c-Fos, $\beta$-actin by Cell Signaling Technology and Sigma (USA). The rest of reagents were obtained from local suppliers.

Tissue. The study was approved by the Institute's Ethics Committee. Effects of potassium ion were studied in tumor tissue (aldosteromas) of the human adrenal cortex.

Conditions of incubation. The adrenal tumor tissue was placed on ice, trimmed from fat and connecting tissue and cut into slices. Slices were incubated during $30 \mathrm{~min}$ at $37^{\circ} \mathrm{C}$ in $1 \mathrm{ml}$ of Krebs-Ringer phosphate buffer (pH 7.6) containing $2 \mathrm{mmol} / 1$ $\mathrm{CaCl}_{2}, 20 \mathrm{mmol} / \mathrm{l}$ HEPES, $2 \mathrm{mg} / \mathrm{ml} \mathrm{BSA}$ and $0-8,5 \mathrm{mmol} / 1 \mathrm{KCl}$. At the end of incubation tubes were cooled.

Western blotting. The tissue was homogenized in $200 \mu \mathrm{l}$ of the lysis buffer containing a cocktail of protease and phosphatase inhibitors, homogenate were centrifuged for $15 \mathrm{~min}$ at $15,000 \mathrm{~g}$ and stored at $-60{ }^{\circ} \mathrm{C}$ until use. Protein concentration was determined according to Bradford [11]. Protein samples were boiled in the sample buffer (100 mmol/1 Tris- $\mathrm{HCl}$, 4\% sodium dodecyl sulfate, $0.2 \%$ bromophenol blue, $20 \%$ glycerol, $10 \%$ dithiothreitol) and separated by SDS-PAGE 9\% gels [12]. $30 \mu \mathrm{g}$ of protein were applied per each lane. Proteins were transferred onto nitrocellulose membranes Hybond-C (Amersham Life Science, UK) by semidry blotting. Membranes were blocked with Tris-buffered saline/0.1\% Tween 20 containing $5 \%$ nonfat dry milk and incubated with primary antibodies for $1 \mathrm{~h}$ at RT. After washing three times with Tris-buffered saline/0.1\% Tween 20 , the blots were incubated with horseradish peroxidase-conjugated species-specific secondary antibody for $1 \mathrm{~h}$ at room temperature and then were again washed three times. Complexes were visualized using the ECL reagents (Amersham Life Science, UK). As loading control $\beta$-actin was used. $\mathrm{X}$-ray films were photographed by a digital video camera, scanned using «Gel Pro Analyzer» v. 4.0 software.

Statistics. All data were expressed as a mean \pm M. Differences between groups were examined for statistical significance using Student's t-test. $\mathrm{P}<0.05$ denoted the presence of a statistically significant difference.

\section{Results and discussion}

Activity of MAPK and its downstream transcription factors was associated with apoptotic or proliferative processes [13]. In addition it was suggested that this cascade kinases participate in the gluco- and mineralocorticoids biosynthesis regulation $[14,15]$. c-Fos is one of the main transcription factor activated by MAPK. To study the effect of $\mathrm{K}^{+}$on transcription factor cFos expression and activation, Western blotting of the proteins from tissue of the human adrenal cortex tumor (aldosteroma) incubated at different potassium concentrations was performed. The decrease of $\mathrm{K}^{+}$concentration in incubation medium from basal, physiological $3.5 \mathrm{mmol} / 1$ to 0 causes 1.3-fold decrease of c-Fos quantity (Fig. 1, 2). Rise of potassium content to $8.5 \mathrm{mmol} / \mathrm{l}$ - the concentration that stimulates steroidogenesis under normal conditions - did not change the cFos level after $30 \mathrm{~min}$ of incubation (Fig. 1, 2).

There are no reports in the literature on changes in the level of the nuclear transcription factors under the influence of potassium ions on the adrenocortical tissue. However, the participation of the c-Jun factor in the potassium effect implementation was shown on cerebral neurons. Potassium increased the level of c-Jun protein in the cells and also accelerated the formation of the transcription factor AP-1 as a homodimer com-

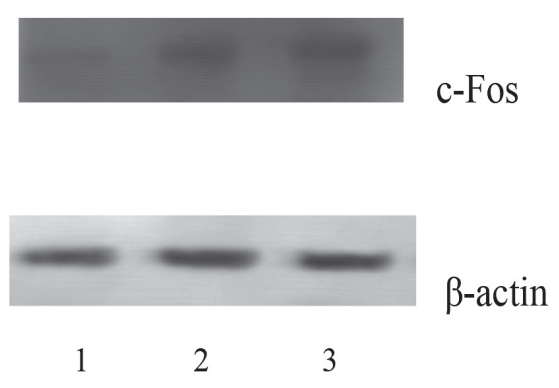

Fig. 1. Representative Western-blot analysis of c-Fos, $\beta$-actin in adrenocortical tumors after $\mathrm{K}+$ administration.

One case of 3 studied is exemplified. 1 - medium without $\mathrm{KCl}$, 2-3.5 mmol// KCl, 3-8.5 mmol// KCl. 
ORBITARY

UNITS

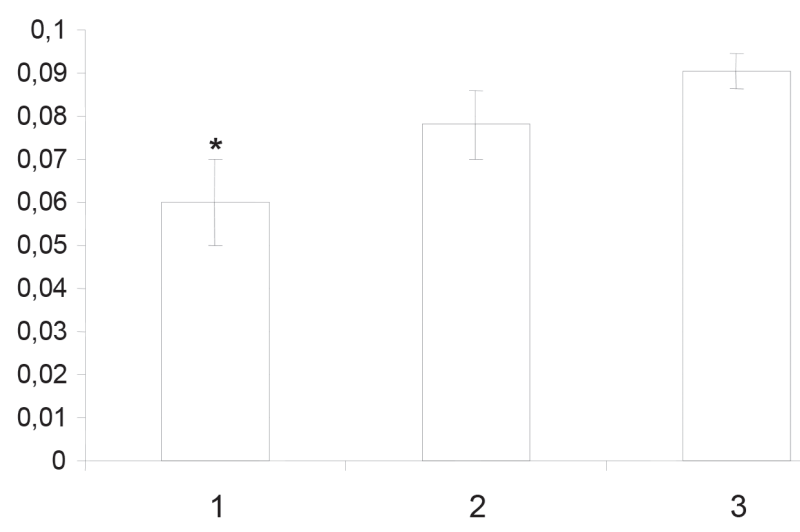

Fig. 2. Effects of $K+$ on c-Fos level in adrenocortical tumor tissue (densitomic measurements) $(\mathrm{M} \pm \mathrm{m} \mathrm{n}=3)$.

1 - medium without $\mathrm{KCl}, 2-3.5 \mathrm{mmol} / \mathrm{K} \mathrm{KCl}, 3-8.5 \mathrm{mmol} / \mathrm{I} \mathrm{KCl}$.

* - $\mathrm{p}<0.05$ in comparison with $3.5 \mathrm{mmol} / \mathrm{l} \mathrm{KCl}$, t-test.

plex c-Jun, or heterodimer c-Jun/JunB. The level of two AP-1 transcriptional targets (Bim and FasL) was also increased [16].

Using the Western blotting method a translocation of protein kinase C (PKC) $\alpha$ from cytosol to membranes was showed after adrenal tissue preincubation in the medium with increased $\mathrm{K}^{+}$ content $(8.5 \mathrm{mmol} / \mathrm{l})$. The translocation means an activation of the enzyme. After incubation of slices in a medium without potassium, the activity of PKC in the microsomes decreases, compared to the activity at the physiological concentration of potassium ions $(3.5 \mathrm{mmol} / \mathrm{l})$. [1]. On the other hand, PKC is a regulator of transcription factor AP-1 which play the role on steroidogenesis regulation and $\mathrm{c}-\mathrm{Fos}$ is a member of the activator protein-1 (AP-1) family of transcription factors.

Thus, a decrease in the expression of transcription factor c-Fos in the potassium ions free incubation medium may indicate the involvement of c-Fosin theinhibitory mechanisms of aldosterone synthesis in adrenocorticocytes with potassium concentrations below physiological parameters.

It was shown that the rise of $\mathrm{K}^{+}$concentration to $5.5-11 \mathrm{mmol} / \mathrm{l}$ caused intensification of DNA laddering in conventionally normal human adrenal tissue. On the contrary, the high $\mathrm{K}^{+}$concentration (elevated) decreases the intensity of DNA laddering in tumor tissues [1]. We can conclude that MAPK/c-Fos activation does not represent the mechanisms responsible for such difference.
The results presented here demonstrate that $\mathrm{K}^{+}$ can have a direct effect on the expression level of nuclear transcription factor c-Fos in the human aldosteroma tissues. This is evidence for involving MAPK to mediate $\mathrm{K}^{+}$effects in adrenocorticocytes. However, the mechanisms of c-Fos-cellular signaling remain unclear. Therefore, further studies should be performed to identify c-Fos target genes in the human adrenal cortex.

\section{Conclusions}

The results of study suggest that $\mathrm{K}^{+}$can have a direct effect on the expression level of nuclear transcription factor c-Fos in tissues from human aldosteromas.

\section{References}

1. Пушкарьов ВМ. Біохімічні механізми регуляції стероїдогенезу в корі надниркових залоз іонами калію. Автореф. дис. ... доктора біол. наук: Київ, 2005:34 c. (PushkarevVM. Biochemical mechanisms of steroidogenesis regulation in the adrenal cortex by potassium ions. Avtoref. dys. ... doktora biol. nauk: Kyiv, 2005:34 p.).

2. Zhu J, Zang S, Chen X, Jiang L, Gu A, Cheng J, et al. Involvement of the delayed rectifier outward potassium channel Kv2.1 in methamphetamine-induced neuronal apoptosis via the p38 mitogen-activated protein kinase signaling pathway. J Appl Toxicol. 2018 May;38(5):696-704.

3. Ali BH, Za'abi MA, Karaca T, Suleimani YA, Balushi KA, Manoj P, et al. Potassium bromate-induced kidney damage in rats and the effect of gum acacia thereon. Am J Transl Res. 2018 Jan;10(1):126-37.

4. Hyatt PJ, Tait JF, Tait SA. The mechanism of the effect of K+ on the steroidogenesis of rat zona glomerulosa cells of the adrenal cortex: role of cyclic AMP. Proc R SocLond B Biol Sci. 1986 Feb;227(1246):21-42.

5. Betancourt-Calle S, Jung EM, White S, Ray S, Zheng X, Calle RA, et al. Elevated $\mathrm{K}(+)$ induces myristoylated alanine-rich C-kinase substrate phosphorylation and phospholipase D activation in glomerulosa cells. Mol Cell Endocrinol. 2001 Nov;184(1-2):65-76.

6. Pushkarev VM, Mikosha AS. The participation of cAMP and protein kinase $\mathrm{C}$ in the regulation of aldosterone biosynthesis by potassium. Biomed Sci. 1991 Feb;2(2):135-9.

7. Ganguly A, Chiou S, Fineberg NS, Davis JS. Greater importance of $\mathrm{Ca}(2+)$-calmodulin in maintenance of ang II- and $\mathrm{K}(+)$-mediated aldosterone secretion: lesser role of protein kinase C. Biochem Biophys Res Commun. 1992 Jan;182(1):254-61.

8. Jiang KW, Yu ZS, Shui QX, Xia ZZ. Activation of ATP-sensitive potassium channels prevents the cleavage of cytosolic mu-calpain and abrogates the elevation of nuclear c-Fos and c-Jun expressions after hypoxic-ischemia in neonatal rat brain. Brain Res Mol Brain Res. 2005 Jan;133(1):87-94.

9. Panguluri SK, Tur J, Chapalamadugu KC, Katnik C, Cuevas J, Tipparaju SM. MicroRNA-301a mediated regulation of Kv4.2 in diabetes: identification of key modulators. PLoS One. 2013 Apr;8(4): e60545.

10. Kwak Y, Han J, Rhyu MR, Nam TS, Leem JW, Lee BH. Different spatial expressions of c-Fos in the nucleus of the solitary tract following taste stimulation with sodium, potassium, and ammonium ions in rats. J Neurosci Res. 2015 Feb;93(2):340-9.

11. Bradford MM. A rapid and sensitive method for the quantitation of microgram quantities of protein utilizing the principle of proteindye binding. Anal Biochem. 1976 May;72:248-54.

12. Laemmli UK. Cleavage of structural proteins during the assembly of the head of bacteriophage T4. Nature. 1970 Aug;227:680-5. 
Оригінальні дослідження

13. Roskoski RJr. ERK1/2 MAP kinases: structure, function, and regulation. Pharmacol Res. 2012 Aug;66(2):105-43.

14. Otis M, Gallo-Payet N. Role of MAPKs in angiotensin II-induced steroidogenesis in rat glomerulosa cells. Mol Cell Endocrinol. 2007 Jan;265-266:126-30.

15. Vargas VE, Kaushal KM, Monau TR, Myers DA, Ducsay CA. Extracellular signal-regulated kinases (ERK1/2) signaling pathway plays a role in cortisol secretion in the long-term hypoxic ovine fetal adrenal near term. Am J Physiol Regul Integr Comp Physiol. 2013 Apr;304(8): R636-43.

16. Ma C, Ying C, Yuan Z, Song B, Li D, Liu Y, et al. dp5/HRK is a c-Jun target gene and required for apoptosis induced by potassium deprivation in cerebellar granule neurons. J Biol Chem. 2007 Oct;282(42):30901-9.

17. J Biol Chem. 2007 Oct;282(42):30901-9.

(Надійшла до редакції 12.11.2018 р.)

\section{Уровень ядерного фактора c-Fos в клетках альдостеромы человека под влиянием калия}

\section{О.С. Лукашеня, Н.И. Левчук}

ГУ «Институт эндокринологии и обмена веществ им. В.П. Комиссаренко НАМН Украины», г. Киев

Резюме. Ионы калия играют важную роль в регуляции стероидогенеза, водно-солевого баланса, апоптоза, пролиферации. Однако ядерный этап переноса сигнала агониста в адренокортикоцитах остается малоизученным. Целью работы было определение действия ионов калия на уровень ядерного фактора транскрипции с-Fos в опухолях коры надпочечников (альдостеромах) человека. Методы. Экспрессию фактора транскрипции c-Fos определяли в альдостеромах с помощью вестерн-блот анализа. Результаты. При физиологической концентрации ионов калия 3,5 ммоль/л наблюдалось увеличение уровня фактора с-Fos в клетках альдостеромы человека по сравнению с таковым в инкубационной среде без калия. При воздействии 8,5 ммоль/л ионов калия уровень c-Fos не изменялся. Обсуждается возможное участие транскрипцион- ного фактора c-Fos в стероидогенных эффектах $\mathrm{K}^{+}$. Вывод. Показано, что $\mathrm{K}^{+}$может непосредственно влиять на уровень экспрессии ядерного транскрипционного фактора с-Fos в ткани альдостером человека.

Ключевые слова: ионы калия, адренокортикоциты человека, альдостерома, факторы транскрипции.

\section{Рівень ядерного чинника c-Fos у клітинах альдостероми людини під впливом калію}

\section{О.С. Лукашеня, Н.І. Левчук}

ДУ «Інститут ендокринології та обміну речовин ім. В.П. Комісаренка НАМН України», м. Київ

Резюме. Іони калію відіграють важливу роль у регуляції стероїдогенезу, водно-сольового балансу, апоптозу, проліферації. Проте ядерний етап перенесення сигналу агоніста в адренокортикоцитах залишається мало вивченим. Метою роботи було визначення дії іонів калію на рівень ядерного чинника транскрипції c-Fos у пухлинах кори надниркових залоз (альдостеромах) людини. Методи. Експресію чинника транскрипції c-Fos визначали в альдостеромах за допомогою вестерн-блот аналізу. Результати. За фізіологічної концентрації іонів калію 3,5 ммоль/л спостерігалося збільшення рівня чинника c-Fos у клітинах альдостероми людини порівняно 3 таким в інкубаційному середовищі без калію. Під дією 8,5 ммоль/л іонів калію рівень CFos не змінювався. Обговорюється можлива участь транскрипційного чинника c-Fos у стероїдогенних ефектах $\mathrm{K}^{+}$. Висновок. Показано, що $\mathrm{K}^{+}$може безпосередньо впливати на рівень експресії ядерного транскрипційного чинника c-Fos у тканині альдостером людини.

Ключові слова: іони калію, адренокортикоцити людини, альдостерома, чинники транскрипції. 